\title{
The effect of increased polyunsaturated fatty acid levels in mixtures supplemented with ascorbate and $\alpha$-tocopherol acetate on slaughter traits of pigs
}

\author{
J. Skomial , E. Sawosz, M. Gagucki and A. Wrzesińska
}

Department of Animal Nutrition and Feed Management.

Warsaw Agricultural University

Rakowiecka 26/30, 02-528 Warszawa, Poland

\begin{abstract}
In an experiment carried out on 28 fattening pigs allocated to four groups, the animals were fed with mixtures containing $4.0 \%$ fish oil and linseed oil (1:1) supplemented with ascorbate or ascorbate and $\alpha$-tocopherol acetate. Daily weight gain and slaughter traits were evaluated, as was the chemical composition of the longissimus dorsi muscle. The highest daily weight gain was observed in groups of animals fed mixtures with oil and oil with ascorbate and $\alpha$-tocopherol acetate. There were no significant differences in backfat thickness and loin eye area. Also the dry matter and fat content in $M$. longissimus dorsi were similar. The protein content was relatively higher in animals fed the control diet and the diet supplemented with oil and ascorbate.
\end{abstract}

KEY WORDS: oil, ascorbate, $\alpha$-tocopherol acetate, fatteners

\section{INTRODUCTION}

The addition of oil to diets for fattening pigs increases their metabolizable energy value, which can improve protein utilization and daily weight gain. Dietary polyunsaturated fatty acids, particularly n-3 PUFA, can modify fatty acid proportions in animal tissue (Lin at al., 1989) as well as improve the functioning of structural lipids, thereby stimulating all metabolic processes (Packer and Landvik, 1989) and, probably, improving the qualitative and quantitative development of tissues in growing animals. Vitamin E stabilizes PUFA contained in membrane lipids and prevents the onset of lipid oxidation, leading to increased biological effectiveness 
of PUFA and influences the development of animal tissues during growth (Anderson et al., 1995). Ascorbate takes part in reconversion of vitamin E, which allows more effective utilization of this vitamin consumed with the diet (Packer, 1991).

The aim of this study was to determine the influence of adding oil to the diet on slaughter traits in pigs receiving mixtures containing $\alpha$-tocopherol acetate, sodium ascorbate, or both of these antioxidants.

\section{MATERIAL AND METHODS}

The experiment was carried out on 28 pigs allocated to 4 groups. The animals were fed individually with complete mixtures from about 25 to $105 \mathrm{~kg}$ body weight; one mixture was used for the entire period of fattening. All mixtures contained about $13 \mathrm{~g}$ of crude protein per MJ ME. Pigs from the control group received the mixture without oil. The other mixtures contained $4 \%$ of oil (a 1:1 mixture of fish by-product oil and linseed oil). Mixtures for groups III and IV were supplemented with sodium ascorbate and, for group IV, additionally with $\alpha$-tocopherol acetate (Table 1). At the end of fattening, all cooled right half-carcasses were partly dis-

TABLE 1

Composition of diets

\begin{tabular}{lcccc}
\hline & \multicolumn{4}{c}{ Group } \\
\cline { 2 - 5 } Compound & control & oil & oil + ascorbate & $\begin{array}{c}\text { oil + ascorbate } \\
+\alpha \text {-tocopherol acetate }\end{array}$ \\
\hline Ground wheat & 10.0 & 10.0 & 10.0 & 10.0 \\
Ground barley & 68.7 & 60.2 & 59.9 & 59.6 \\
Wheat bran & 1.5 & 1.5 & 1.5 & 1.5 \\
Soyabean oilmeal & 12.0 & 16.5 & 16.5 & 16.5 \\
Meat meal & 5.0 & 5.0 & 5.0 & 5.0 \\
Oil & & 4.0 & 4.0 & 4.0 \\
Sodium ascorbate & & & 0.3 & 0.3 \\
$\alpha$-Tocopherol acetate & & & & 0.3 \\
CaHPO4 & 0.2 & 0.2 & 0.2 & 0.2 \\
CaCO3 & 1.0 & 1.0 & 1.0 & 1.0 \\
NaCl & 0.6 & 0.6 & 0.6 & 0.6 \\
Mineral-vitamin mixture & 1.0 & 1.0 & 1.0 & 1.0 \\
& & & & \\
In l kg of mixture & & & & 13.30 \\
ME*, MJ & 12.42 & 13.38 & 13.34 & 8.75 \\
crude protein, g & 163 & 171 & 172 & 5.83 \\
lysine* m & 7.99 & 8.78 & 8.76 & \\
methionine, g & 5.64 & 5.85 & 5.84 & \\
\hline
\end{tabular}

* - calculated on a base of Polish Pig Fecding Standards (1993) 
sected according to the method used at Polish Pig Testing Stations: the backfat thickness, loin eye area (between rib 13 and 14 rib) and meat in primal cuts were evaluated (Różycki, 1996). The chemical composition of meat (M. longissimus dorsi) was determined using standard methods.

The results were analyzed statistically using Anova analysis of variance with Duncan's multiple range test (Statgraphics 6.0 Plus).

\section{RESULTS}

The weight gain of all fattening pigs exceeded $750 \mathrm{~g}$ (Table 2). The highest gains were observed in groups of fatteners receiving oil and oil with ascorbate and $\alpha$-tocopherol acetate ( 813 and $794 \mathrm{~g}$, respectively). The differences between groups I and III vs II and IV were statistically significant. There were no significant differences in backfat thickness, however. The thinnest backfat was observed in fatteners that grew fastest. The loin eye area did not differ statistically between treatments. Also the quantity of meat in primal cuts was very similar in all groups, but slightly bigger values were noticed in groups receiving oil in mixtures. There were no statistical differences in chemical composition of longissimus dorsi muscle except for protein content - the highest value was observed in animals fed the control diet and supplemented with oil and ascorbate. However, the dry matter content was higher in animals fed the diet with added oil.

TABLE 2

Daily weight gain and carcass characteristic

\begin{tabular}{|c|c|c|c|c|c|c|}
\hline \multirow[b]{2}{*}{ Item } & \multicolumn{4}{|c|}{ Group } & \multicolumn{2}{|c|}{ ANOVA } \\
\hline & control & oil & $\begin{array}{c}\text { oil } \\
+ \text { ascorbate }\end{array}$ & $\begin{array}{c}\text { oil }+ \text { ascorbate } \\
+\alpha \text {-tocopherol } \\
\text { acetate }\end{array}$ & $\mathrm{P}$ & SEM \\
\hline Daily weight gain, $\mathrm{g}$ & $766^{b}$ & $813^{\circ}$ & $759^{b}$ & $794^{a}$ & 0.027 & 11.67 \\
\hline Half carcass weight, $\mathrm{kg}$ & 38.4 & 39.1 & 38.4 & 38.7 & 0.616 & 0.48 \\
\hline Half carcass length, $\mathrm{cm}$ & 75.7 & 77.1 & 75.8 & 76.0 & 0.727 & 0.99 \\
\hline Backfat thickness, cm & 2.73 & 2.49 & 2.84 & 2.80 & 0.498 & 0.17 \\
\hline Loin eye area, $\mathrm{cm}^{2}$ & 41.3 & 41.3 & 41.0 & 41.6 & 0.998 & 2.17 \\
\hline Meat in primal cuts, $\mathrm{kg}$ & 18.4 & 19.1 & 18.2 & 19.0 & 0.852 & 1.19 \\
\hline $\begin{array}{l}\text { Composition of meat } \\
\text { dry matter, } \%\end{array}$ & 27.86 & 28.43 & 28.27 & 28.01 & 0.847 & 0.49 \\
\hline protein, $\%$ & $25.55^{\mathrm{a}}$ & $24.28^{\mathrm{bd}}$ & $25.02^{c}$ & $24.66^{\mathrm{b}}$ & 0.017 & 0.27 \\
\hline ether extract, $\%$ & 2.62 & 2.94 & 2.71 & 2.49 & 0.624 & 0.25 \\
\hline
\end{tabular}

$\mathrm{a}, \mathrm{b}, \mathrm{c}, \mathrm{d}-\mathrm{P}<0.05$ 


\section{DISCUSSION}

Oil added to the mixtures increased their energy value, but fatteners in the control group received relatively more feedstuff so that energy and protein consumption were similar in all groups. This supports the conclusion that the increase in daily weight gain in pigs receiving oil in mixtures is caused by increased n-3 PUFA in feeds. However, this was not observed in group III in which ascorbate was added. Fatteners fed mixtures supplemented with both antioxidants grew as fast as those fed with oil but without antioxidants.

Polyunsaturated fatty acids (PUFA) from the n-3 series and particularly $\alpha$-linolenic acid may influence the intensity of metabolism by increasing the effectiveness of transport of lipoprotein molecules in blood (Chan, 1998) and through the plasma membrane (Clamp et al., 1997). This may stimulate the anabolic process leading to an increase of daily weight gain without increasing backfat thickness. It is also suggested that the n-3 PUFA can be better utilized as an energy source for protein synthesis than others. Other authors (Morgan, 1992; Sawosz et al., 2001) obtained results similar to those achieved in the present experiment. Smith et al. (1996) observed that lipogenesis in adipose tissue of pigs fed on diets supplemented with 18:2 fatty acids was higher than in pigs that received 16:0 fatty acids. However, in other papers it is suggested that linolenic acid present in adipose tissue can stimulate lipogenesis in pigs, which and ultimately leads to an increase in backfat thickness without improvement of daily weight gain (Mourout et al., 1994).

$\alpha$-Tocopherol acetate present in the plasma membrane protects PUFA from degradation, which ensures their stable level and prevents the peroxidation of lipids. However $\alpha$-tocopherol did not influence the examined indices. Sodium ascorbate did not improve the results; daily weight gain was even lower than in the group without this supplement.

\section{CONCLUSIONS}

Oil (fish by-product oil and linseed oil) added to the feed mixture at $4 \%$, causes an increase in the daily weight gain of fatteners. Neither $\alpha$-tocopherol acetate $(0.3 \%)$, sodium ascorbate $(0.3 \%)$ nor the added oil influenced weight gain and slaughter traits. 


\section{REFERENCES}

Anderson L.E., Myer R.O., Brendemuhl J.M., McDowell L.R., 1995. The effect of excessive dietary vitamin $A$ on performance and vitamin $E$ status in swine fed diets varying in dietary vitamin $E$. J. Anim. Sci. 73, 1093-1098

Chan A.C., 1998. Vitamin E and atherosclerosis. J. Nutr. 128, 1593-1596

Clamp A.G., Ladha S., Clark D.C., Grimble R.F., Lund E.K., 1997. The influence of dietary lipids on the composition and membrane fluidity of rat hepatocyte plasma membrane. Lipids 32, 179-184

Lin C.F., Gray J.I., Asghar A., Buckley D.J., Booren A.M., Flegal C.J., 1989. Effects of dietary oils and alpha tocopherol supplementation on lipid composition and stability broiler meat. J. Food Sci. 54, 1457-1460

Morgan C.A., 1992. Manipulation of the fatty acid composition of the pig meat lipids by dietary means. J. Sci. Food Agr. 58, 357-368

Mourout J., Camara M., Fevrier C., 1994. Effect of two dietary fats on lipogenesis and on meat quality of pig. Proceedings of $45^{\text {th }}$ EAAP Mecting, Edinburgh (UK)

Packer L., 1991. Protective role of vitamin E in biological systems. Amer. J. Clin. Nutr. 53, 1050S. $1055 \mathrm{~S}$

Packer L., Landvik K.U., 1989. Vitamin E: introduction to biochemistry and health benefits. Ann. NY Acad. Sci. 570, 7-23

Różycki M., 1996. Principles of slaughter value estimation in Pig Progeny Stations. The state of breeding and the results of pig evaluation (in Polish). Research Institute of Animal Production Press, Kraków (Poland), XIV, 69-82

Sawosz E., Skomial J., Gagucki M., Wrzesińska A., 2001. Effect of enrichment of feed mixtures in polyunsaturated fatty acids and vitamin $\mathrm{E}$ on indices of pig carcass quality (in Polish). Warsaw Agr. Univ. SGGW, Anim. Sci. (in press)

Smith D.R., Knabe D.A., Smith S.B., 1996. Depression in lipogenesis in swine adipose tissue by specific dietary fatty acids. J. Anim. Sci. 74, 975-983

\section{STRESZCZENIE}

\section{Wplyw uzupelniania mieszanek nienasyconymi kwasami tluszczowymi oraz askorbinianem i octanem $\alpha$-tokoferolu na przyrosty i wyniki poubojowe tuczników}

W doświadczeniu przeprowadzonym na 28 tucznikach, podzielonych na 4 grupy, żywionych mieszankami zawierającymi $4,0 \%$ oleju, oraz uzupełnionymi askorbinianem lub askorbinianem i octanem $\alpha$-tokoferolu oceniano przyrosty masy ciała, wskaźniki jakości tuszy i skład chemiczny mięśnia najdłuższego grzbietu longissimus dorsi. Zwierzęta żywionc mieszankami z olejem oraz olejem, askorbinjanem i octanem $\alpha$-tokoferolu mialy największe przyrosty masy ciała. Nie stwierdzono różnic statystycznie istotnych w grubości słoniny grzbictowej i powierzchni oka polędwicy. Także zawartość suchej masy i tuszczu w mięśniu longissimus dorsi była podobna we wszystkich grupach. Zawartość białka była stosunkowo większa u zwierząt żywionych dietą kontrolną oraz $\mathrm{z}$ dodatkiem oleju i askorbinianu niż u pozostałych. 